Double stratospause structure

\title{
Rayleigh lidar observations of double stratopause structure over three different northern hemisphere stations
}

\section{Sivakumar et al.}

V. Sivakumar ${ }^{1}$, H. Bencherif ${ }^{1}$, A. Hauchecorne ${ }^{2}$, P. Keckhut ${ }^{2}$, D. N. Rao ${ }^{3}$, S. Sharma ${ }^{4}$, H. Chandra ${ }^{4}$, A. Jayaraman ${ }^{4}$, and P. B. Rao ${ }^{5}$

${ }^{1}$ Laboratoire de l'Atmosphère et des Cyclones, CNRS-UMR 8105, Université de La Réunion, La Reunion, France

${ }^{2}$ Service d'Aéronomie, CNRS, Paris, France

${ }^{3}$ National Atmospheric Research Laboratory, P. B. No: 123, Tirupati-517 502, India

${ }^{4}$ Physical Research Laboratory, Navarangapura, Ahmedabad-380 009, India

${ }^{5}$ National Remote Sensing Agency, Bala Nagar, Hyderabad-500 037, India

Received: 15 June 2006 - Accepted: 7 July 2006 - Published: 25 July 2006

Correspondence to: V. Sivakumar (siva@univ-reunion.fr)

Title Page

Abstract

Introduction

Conclusions

References

Tables

Figures

14

$\rightarrow 1$

4

Back

$>$

Close

Full Screen / Esc

Printer-friendly Version

Interactive Discussion 


\section{Abstract}

Using four years of Rayleigh lidar data collected from three different northern hemisphere stations (Gadanki $13.5^{\circ} \mathrm{N}, 79.2^{\circ} \mathrm{E}$; Mt. Abu $24.5^{\circ} \mathrm{N}, 72.7^{\circ} \mathrm{E}$ and Observatoire de Haute Provence: OHP; $44^{\circ} \mathrm{N}, 6^{\circ} \mathrm{E}$ ), the characteristics of double (separated) 5 stratopause occurrence are presented here, for the first time. The characteristics are illustrated by a seasonal change during summer and winter and the variation in percentage of occurrence from place to place. It is found that the over-all mean normal stratopause (NS) positioned at the middle level of double stratopause (upper and lower level) with its location nearer to the lower level of double stratopause (LDS) than to the upper level of double stratopause (UDS). The frequency distribution of NS, LDS and UDS demonstrated variability with location, indicating role of dynamical activity. By making use of a quasi-continuous 40 days of lidar observations over Gadanki and OHP, the responsibility of Gravity Wave (GW) and Planetary Wave (PW) activity for the LDS and UDS occurrence are examined and presented.

\section{Introduction}

The Earth's atmosphere is characterized by thermal layers showing alternatively negative and positive temperature gradients. The stratopause is a transition section that separates stratosphere and mesosphere. It corresponds to the height where a maximum temperature occurs. It is usually located in the height region from $45 \mathrm{~km}$ to $55 \mathrm{~km}$, throughout the globe. Changes in the stratosphere/mesosphere could occur due to different propagating atmospheric waves and to the presence of radiative chemical constituents (ozone) (Hitchman et al., 1989; Singh et al., 1996). The above sources also play a significant role in modifying the thermal structure at, above and below the stratopause region (mesosphere and troposphere).

25 Using rocket measurements Gupta et al. (1978) reported on the double stratopause cases over Thumba $\left(8.3^{\circ} \mathrm{N} ; 76.5^{\circ} \mathrm{E}\right)$ in their climatological study. They found that

6, 6933-6956, 2006

Double stratospause structure

V. Sivakumar et al.

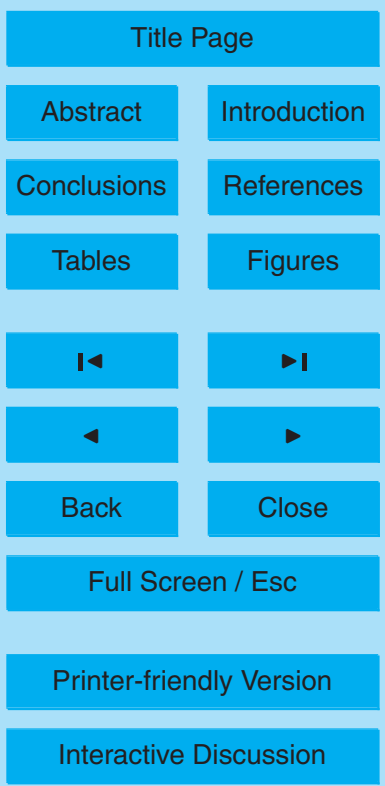

EGU 
the occurrences of double stratopauses are quite frequent $(\sim 20 \%)$ and the two stratopause altitudes are apart the normal stratopause and are separated by $\sim 10 \mathrm{~km}$. Using satellite data, Hitchman et al. (1989) revealed the occurrence of separated stratopauses in both hemispheres and found to be more prominent during winter with

5 time persistence. By using a 2-D model, they suggested that the gravity waves could account for the observed splitting of stratopause by driving circulation in the winter hemisphere. Recently, using Microwave Limb Sounder (MLS) data, Allen et al. (1997) presented the double peak structure in the temperature profiles, one occurring in the stratosphere and another in the lower mesosphere. They found that the structure 10 was in consistency with three dimensional barotropic/baroclinic instability model predictions. In addition to the above measurements, few lidar stations over the globe have reported the occurrence of double stratopause structures (Hauchecorne et al., 1991; Chanin and Hauchecorne, 1991; Leblanc and Hauchecorne, 1997; Sivakumar, 2002). Except the above evidences, there are no systematic detailed studies and no climato15 logical picture on the occurrence of double stratopause.

The present study focuses on detailed features of the occurrence of double stratopause structures in the middle atmospheric temperature profiles (height range of 40-60 km). Three Rayleigh lidar data sets collected during the 1998-2001 period (4 years) at different northern latitudes (tropics, subtropics and mid-latitudes) have been analysed: Gadanki $\left(13.5^{\circ} \mathrm{N}, 79.2^{\circ} \mathrm{E}\right)$; Mt. Abu $\left(24.5^{\circ} \mathrm{N}, 72.7^{\circ} \mathrm{E}\right)$ and Observatoire de Haute Provence (OHP; $\left.44^{\circ} \mathrm{N}, 6^{\circ} \mathrm{E}\right)$. The seasonal (winter and summer) and statistical characteristics of double stratopause occurrence for those sites are investigated. Generating mechanisms of the double stratopause events are also investigated and discussed in terms of wave activity (GW and PW). This is made by the use of a 40-days quasi-continuous data time-series obtained simultaneously over Gadanki and OHP.

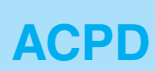

6, 6933-6956, 2006

Double stratospause structure

V. Sivakumar et al.

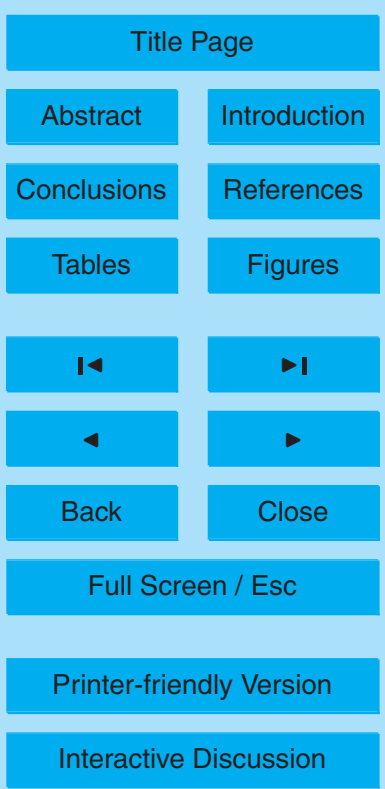




\section{Data and observation}

The Rayleigh lidar data collected during 4 years from 1998 to 2001 in three different stations, such as; Gadanki, Mt. Abu and Observatoire de Haute Provence (OHP) are used for identifying and characterizing the double stratopause structure. The monthly distributions of lidar data used for the three stations are tabulated in the Table 1.

The recorded raw data are in the form of photon count profiles and then the temperature profiles are derived by following the method as given by Hauchecorne and Chanin (1980). Temperature profile retrieval is similar for all the three stations and the error in measurements is $\sim 1-2 \mathrm{~K}$ in the stratosphere height region. More details on the individual lidar systems and methods of analysis may be collected from Sivakumar et al. (2001; 2002; 2003), for Gadanki, from Chandra et al. (2005) for Mt. Abu and from Keckhut et al. (1994) for OHP.

The obtained temperature profiles are used for locating the normal stratopause and double stratopauses (Lower and Upper level of double stratopause). The normal stratopause is defined as the height at which the warmest temperature is observed. The double stratopause cases are systematically checked from individual temperature profiles. The lower or upper level of double stratopause is also referred to normal stratopause depending upon the location of observed warm temperature.

Figure 1 shows typical height profiles of temperature illustrating single/normal and double stratopause cases. It appears from this example that the single (or) normal stratopause (NS) is located at $48.1 \mathrm{~km}, 47.7 \mathrm{~km}$ and $45.0 \mathrm{~km}$, respectively for Gadanki, Mt. Abu and OHP. Whereas, the double stratopause cases illustrate their occurrence of the upper level of double stratopause (UDS) at $53.2 \mathrm{~km}, 54.5 \mathrm{~km}$ and $50.0 \mathrm{~km}$, the lower level of the double stratopause (LDS) at $43.6 \mathrm{~km}, 47.3 \mathrm{~km}$ and $44.0 \mathrm{~km}$, and the 25 vertical distance between them are of $\sim 9.6 \mathrm{~km}, 7.2 \mathrm{~km}$ and $6 \mathrm{~km}$. It appears also that the tropical station, Gadanki, experiences the largest separation in comparison with sub-tropics (Mt. Abu) and the mid-latitude stations (OHP). 


\section{Statistics}

The daily mean temperature profiles are used to identify the double stratopause occurrence and to report on the heights of occurrences of NS, UDS and LDS. The monthly distributions of total number of observations and the number detected dou5 ble stratopause cases are tabulated in Table 1. The percentage of double stratopause occurrence represents the ratio between the number of double stratopause occurrence and the total number of observations. The overall percentage of occurrence shows that it is maximum for Gadanki (63\%) followed by OHP (44\%) and Mt. Abu (42\%). Since the monthly double stratopause occurrences in the databases are less, the distribution are difficult to perform (ref. Table 1), we have investigated the common features observed during two distinct periods with regard to the middle atmosphere seasonal circulation and planetary wave activity: summer and winter. Summer and winter seasons correspond to the six months periods respectively from March to August and from September to February. The percentage of occurrences during summer and winter are found to be $68.1,44.4$ and 45.2 and $58.8,40.5$ and 42.1 , respectively for Gadanki, Mt.Abu and OHP. It indicates a higher percentage of occurrences recorded in summer than in winter for all the three sites. It also further elucidates that the prevalence of double stratopause structure in the temperature profiles is irrespective of place and season. It seems to indicate that this phenomenon is a global one.

20 The frequency distribution of heights of occurrence of NS, LDS and UDS is obtained by grouping the data in terms of summer and winter seasons irrespective of the years (Fig. 2a-c). The observed mean stratopause height for NS, LDS and UDS for summer and winter season is tabulated in Table 2. The following salient points are noted from the Fig. 2 and Table 2;

25 - NS, LDS and UDS generally follow the Gaussian distribution with vastly varying from $38 \mathrm{~km}$ to $57 \mathrm{~km}$ and by displaying the NS at the centre level of LDS and UDS, for all the three stations.

- NS, LDS and UDS distributions are in the range of $40-56 \mathrm{~km}, 40-54 \mathrm{~km}$ and $43-$ 6937

6, 6933-6956, 2006

Double stratospause structure

V. Sivakumar et al.

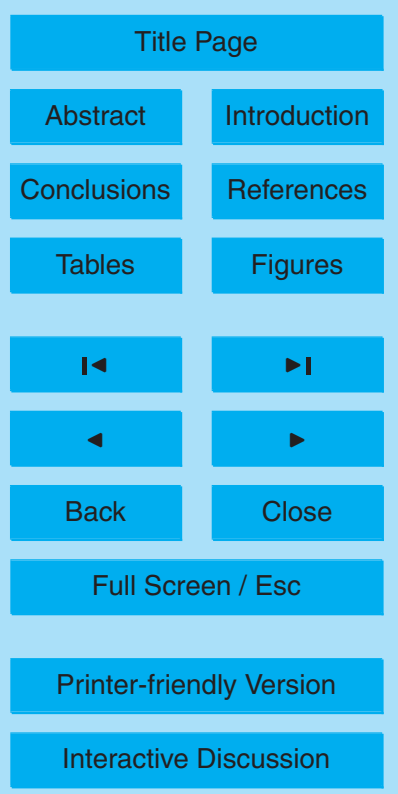


$57 \mathrm{~km}$ and $37-57 \mathrm{~km}, 39-53 \mathrm{~km}$ and $39-57 \mathrm{~km}$ during summer and winter, respectively, with their corresponding mean values at 47.0, 45.6 and $49.8 \mathrm{~km}$ and at 48.6 , 46.5 and $51.0 \mathrm{~km}$, for Gadanki.

- distributions of NS, LDS and UDS for Mt.Abu, ranges within 43-55 km, 37-53 km and $47-57 \mathrm{~km}$ and $41-59 \mathrm{~km}, 41-55 \mathrm{~km}$ and $43-59 \mathrm{~km}$, with mean heights found at $48.1,46.5$ and $53.0 \mathrm{~km}$ and at $47.3,46.8$ and $49.2 \mathrm{~km}$, respectively for summer and winter.

- In case of OHP, the NS, LDS and UDS distributions ranging within 41-56 km, 41$55 \mathrm{~km}$ and $41-57 \mathrm{~km}$ and $37-60 \mathrm{~km}, 37-55 \mathrm{~km}$ and $41-59 \mathrm{~km}$ with mean heights positioned at $48.0,46.5$ and $51.4 \mathrm{~km}$ and at $47.4,45.5$ and $50.9 \mathrm{~km}$, for summer and winter.

- mean heights of occurrence of NS, LDS and UDS are found to be higher in summer than in winter for Mt. Abu and OHP and the reverse for Gadanki (i.e., higher in winter than in summer).

- percentage of occurrence of double stratopause and the mean heights of occurrence of NS, LDS and UDS are found to be nearly same for Mt. Abu and OHP.

\section{Examination of wave activity as a possible generation mechanism}

The above presented statistics suggest that the presence of double stratopause structure is independent of time and places. It is feasible to discuss the causative mechanism for the observed phenomenon. It is well known that the perturbations in stratosphere-mesosphere temperature profiles are either due to propagating atmospheric waves or composition changes in radiative chemical constituents. The changes due to chemical constituents does not happen suddenly and do not disappear in a short period of time ( 1-2 days). Hence, the propagating atmospheric waves could be the

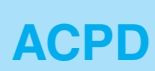

6, 6933-6956, 2006

Double stratospause structure

V. Sivakumar et al.

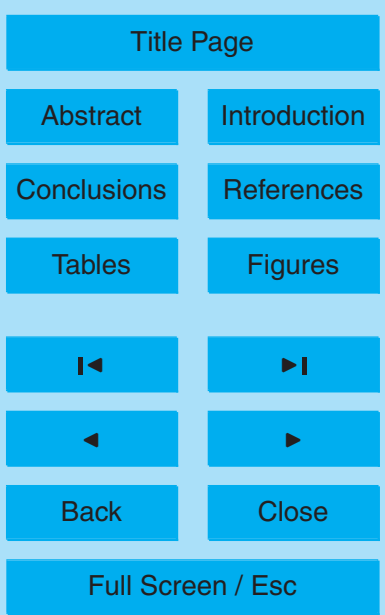

Printer-friendly Version

Interactive Discussion 
main source for altering the temperature and thereby impact the temperature variations in the stratopause height region as reported in Sect. 3.

Generally, two kinds of propagating waves are responsible for perturbing the middle atmospheric temperature, such as, the planetary wave (PW) and gravity wave (GW), 5 which might be the potential source for generating the double stratopause structure. Also, we suspect that the LDS and UDS occurrence possibly may have a strong relationship to the globally addressed phenomena, (a) Sudden Stratospheric Warming (SSW) and (b) Mesospheric Temperature Inversion (MTI). These two middle atmospheric phenomena are again commonly addressed with the PW/GW propagation and 10 breaking. Here, in the following sub-sections, the role of GW and PW activity is explored for Gadanki and OHP, since the Mt.Abu dataset is smaller. In fact, from the later one can not find any continuous or quasi-continuous data time-series, as it is the case for OHP and Gadanki.

Indeed, the wave activity is examined by using quasi-continuous and simultaneous 15 40-days of lidar observation over Gadanki and OHP, from 18 January 1999 to 28 February 1999. There were few days ( 1 or 2 days) with no observations and those data are filled by linear interpolation. Then, the occurrence height of NS, LDS and UDS for the above period and for Gadanki and OHP is noted and plotted in Fig. 3a-b. It illustrates that Gadanki experiences the double stratopause cases for $87.5 \%$ during the period of observation and in which NS appears on LDS for $40 \%$ and on UDS for $60 \%$. Whereas, OHP observations represent the double stratopause cases for $60 \%$ with NS falls on LDS for $16.7 \%$ and on UDS for $83.3 \%$. The OHP observations demonstrate that NS is more frequently found at UDS than at LDS, whereas, the Gadanki observations show the opposite: NS is more frequent at LDS than at UDS. It is also evident from Fig. 3 that LDS and UDS show large day-to-day variability with typical periodicity of planetary waves in the stratopause region.

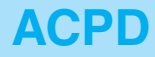

$6,6933-6956,2006$

Double stratospause structure

V. Sivakumar et al.

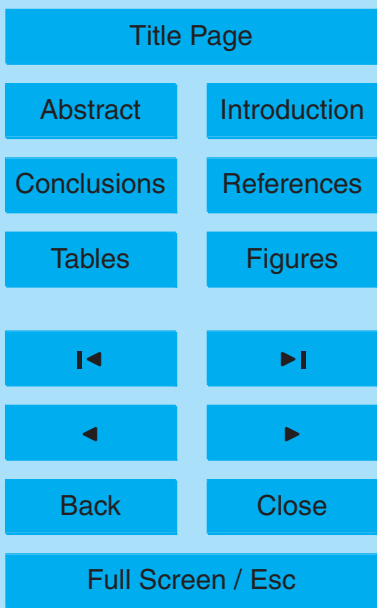

Printer-friendly Version

Interactive Discussion 
Gravity waves (GW), which commonly propagate from troposphere to mesosphere, might be one of a source mechanism to disturb the stratopause region, where GW may break and transfer their energy. Thereby, in this section, we explore the role of 5 GW activity in generating the double stratopause structure for Gadanki and OHP. The GW associated potential energy (P.E) is a parameter which illustrates the strength of GW and the atmospheric stability. Assuming that the GW perturbation could contribute to the double stratopause structure; we computed the GW associated P.E at both LDS and UDS height regions and for Gadanki and OHP. It is calculated by assuming that the atmospheric density perturbations are similar to that of temperature (Wilson et al., $1991 \mathrm{a}, \mathrm{b}$; and Whiteway and Carswell, 1994; 1995) and following the expression given by Wilson et al. (1991a);

$E_{p}=\frac{1}{2}\left(\frac{g}{N}\right)^{2}\left(\frac{T^{\prime}}{T_{0}}\right)^{2}$

where, $T^{\prime}$ is the temperature perturbation evaluated as the difference between temperature profile and a third order polynomial fit $\left(T_{0}\right)$ and $N$ is the Brunt-Väisälä frequency obtained from the following expression,

$N^{2}=\frac{g}{\theta}\left[\frac{d \theta}{d z}+\Gamma\right]$

$\Gamma$ is the adiabatic lapse rate $(=9.8 \mathrm{~K} / \mathrm{km})$ and

$\theta$ is the potential temperature estimated from the third order polynomial fit.

20 Initially, the height profile of P.E is computed for 30 to $70 \mathrm{~km}$ height range, by following the above expression. Thereby, we estimated the mean potential energy for LDS and UDS height regions over Gadanki and presented in Fig. 4a. Here, the LDS and UDS height region ranges from $40.02 \mathrm{~km}$ to $49.02 \mathrm{~km}$ and from $50.81 \mathrm{~km}$ to $59.81 \mathrm{~km}$, respectively. Similarly, the mean potential energy is computed for OHP over LDS height

Double stratospause structure

V. Sivakumar et al.

Title Page

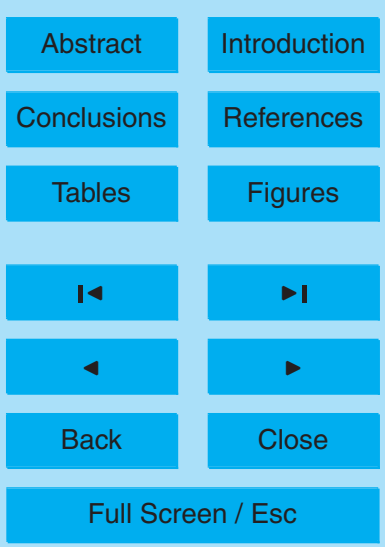

Printer-friendly Version

Interactive Discussion 
region from $43 \mathrm{~km}$ to $48 \mathrm{~km}$ and over UDS height region from $49 \mathrm{~km}$ to $54 \mathrm{~km}$, and plotted in Fig. 4b.

As expected the GW associated P.E increases with height, the calculated mean P.E displays a higher value for UDS than LDS. For both stations, the day-to-day variation 5 of P.E for LDS and UDS are nearly found to be similar, except showing a high value for UDS. Also, the mean value of P.E for OHP is higher than that of Gadanki. In very few cases, extreme high values are recorded for OHP. The recorded high peaks of P.E are found to be coincident with the cases where high differences between LDS and UDS are detected (see Fig. 3). A regressive correlation analysis is performed between P.E 10 values (Fig. 4) and UDS-LDS heights (Fig. 3). It illustrates that the correlation rate for Gadanki between LDS and P.E is about $5.2 \%$, while it is about $37.2 \%$ between UDS and P.E. Whereas, the correlation analysis performed for OHP displays $22.5 \%$ and $46.9 \%$ respectively for LDS versus P.E and UDS versus P.E. The results obtained for Gadanki and OHP show a higher correlation with P.E for UDS than for LDS. It suggests 15 that the GW might be a more generative cause for the observed UDS structures than for the LDS.

Because GW seems to be part of the double stratopause structures, it appears interesting to investigate the possible correlation between UDS and the occurrence of mesospheric temperature inversion (MTI). It has been reported from earlier studies that the temperature inversions are detected above $55 \mathrm{~km}$ for OHP (Hauchecorne et al., 1987) and above $70 \mathrm{~km}$ for Gadanki (Sivakumar et al., 2001; Ratnam et al., 2003). However, the UDS occurrences are obtained below $55 \mathrm{~km}$ for all the three stations (see Fig. 2). Hence, the altitude ranges of UDS and MTI clearly revealed to be two distinct phenomena. Yet, both UDS and MTI may be generated by GW propagation in the 25 upper stratosphere-lower mesosphere region. In fact, previous studies showed that GW breaking is the most probable cause for MTI. Moreover, the estimated P.E is found to be higher for OHP than for Gadanki which is in agreement with the earlier results showing a maximum GW activity during winter at OHP (Wilson et al., 1991b) and during summer equinox at Gadanki (Sivakumar et al., 2006). Thereby, we suggest that

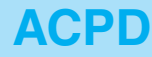

6, 6933-6956, 2006

Double stratospause structure

V. Sivakumar et al.

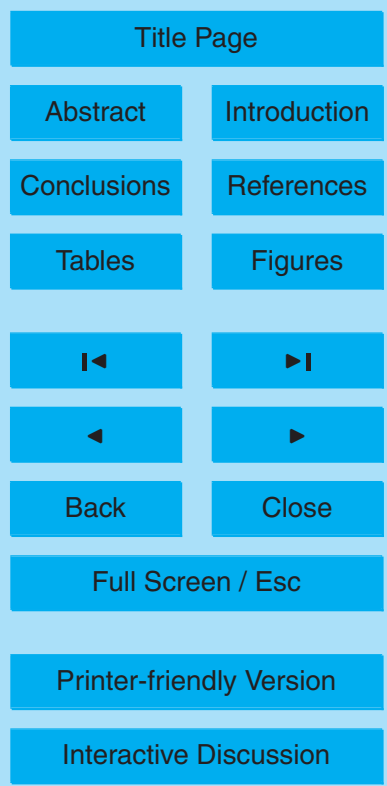


the dominant GW activity may be one of the main sources to contribute for the UDS occurrences.

\subsection{Role of PW activity}

Planetary waves (PW) also contribute to the variability and dynamical changes in the 5 middle atmosphere. Here, we explore a possible role of PW activity in generating the double stratopause structure. We have applied continuous wavelet transform (cwt) to the above quasi-continuous 40-days lidar observations. The wavelet spectral technique extracts the wave parameters into a good time-frequency resolution in comparison with FFT. Generally, FFT is used where there is a fixed window width (like dynamic spectra); where as the width of the wavelet depends on scale of interest (frequency). Also, the narrow/broader wavelet allows high/low frequency (small/large time scale) components to be better resolved in time. As the Morlet wavelet has a well-defined relationship between its scales and the Fourier periods (Malinga and Poole, 2002), we have used the same technique to extract the dominant PW modes. It is subjected to the temperature differences derived by subtracting the 40-days mean temperature profile from the individual daily temperature values. We have computed the PW amplitudes for the height region from $30 \mathrm{~km}$ to $70 \mathrm{~km}$ and examined the $\mathrm{PW}$ periodicities from 5 to 25 days. The examined altitude range are from $40.02 \mathrm{~km}$ to $49.02 \mathrm{~km}$ and from $50.81 \mathrm{~km}$ to $59.81 \mathrm{~km}$, corresponding to LDS and UDS height regions over Gadanki. The obtained PW amplitude is sketched in Fig. $5 \mathrm{a}-\mathrm{b}$. It is clear from the figure that the wave activity is stronger in the LDS height region than in the UDS. It shows a periodicity of 13-20 days (referred hereafter as 13-20 d) observed over the 40-days observational period, with maximum amplitude from 13th to 37th day. Also, there are small period waves of 8-10 d in the first 15 days and $5-7 d$ at the end of observational days (from 35 to 40), but their am25 plitudes are weaker than for PW with period of 13-20 d. With regard to UDS region, it shows smaller amplitudes for the 10-13d wave starting on the 10th day and further a 6-7 d time-localized (15th-25th) with slightly weaker amplitude.

Similar analysis has been done for OHP observations to examine the PW activity.

Double stratospause structure

V. Sivakumar et al.

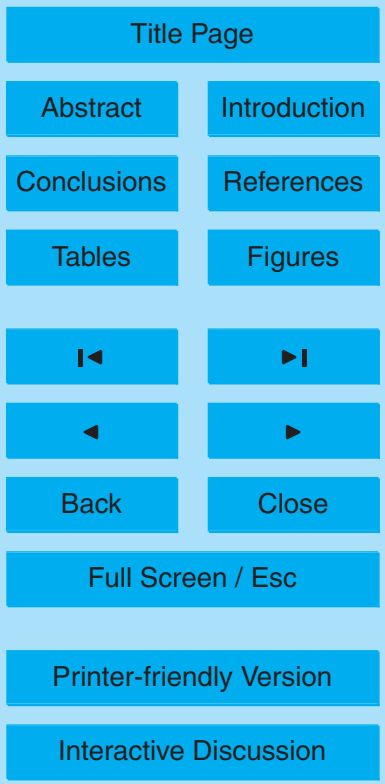


Fig. 6a-b shows the extracted mean PW amplitude for the LDS and UDS region, i.e., from 43 to $48 \mathrm{~km}$ and from 49 to $54 \mathrm{~km}$. The figure displays a 20-25d persistent and dominant wave in the LDS region. In the UDS region, PW amplitudes are weaker than those obtained in the LDS region. The UDS region shows two quasi-persistent 15-20 d wave and a localized (15th-30th) 7-8 d wave.

This result shows that PW amplitudes are higher in LDS than in UDS. It suggests that the PW could be responsible for LDS at both stations (Gadanki and OHP). In addition, the PW amplitude is observed to be higher over mid-latitudes (OHP) than over tropics (Gadanki). This is in agreement with the fact that PW are high- and mid-latitude gener10 ated with equator-ward trajectories, and amplitudes are smaller in the tropics (Barnett and Labitzke, 1990). Also, the obtained results are in accordance with the recently reported SSW event observed over Gadanki (Sivakumar et al., 2004). The warming event is observed at the stratopause height, in concordance with the PW disturbances observed over high- and mid-latitudes, propagating upward and equator-ward. Simi-

larly, the observations reported at mid-latitude stations (e.g., OHP) also show higher warming amplitude with predominant PW activity during winter in the stratosphere (Hauchecorne et al., 1983; Leblanc et al., 1998). The above results also suggested that the PW activity is higher during winter in connection to the stratospheric warming.

Moreover, we examined PW activity using continuous ECMWF meteorological and zonal fields at $45^{\circ} \mathrm{N}$ and $15^{\circ} \mathrm{N}$ derived for the same 40-days period. Similarly, higher wave amplitudes are found at $45^{\circ} \mathrm{N}(\mathrm{OHP})$, in comparison with wave amplitudes at $15^{\circ} \mathrm{N}$ (Gadanki) (figures are not shown). The PW amplitudes according to altitudes show that the values are decreasing with height. In other sense, it could indicate that the LDS height occurrence may be related to the PW activity, during winter, especially.

\section{Conclusions}

For the first time, a climatological lidar analysis of double stratopause structures is reported from three different stations over the northern hemisphere. The observations

Double stratospause structure

V. Sivakumar et al.

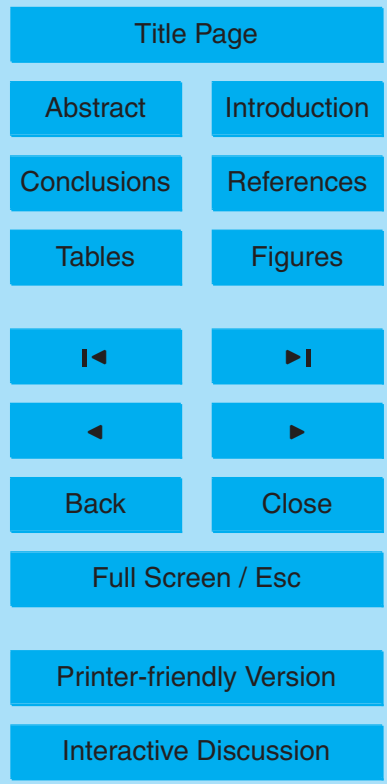


from mid-, sub-tropical and low-latitude stations show that the structure exists over the globe, with seasonal and latitudinal variations. The high- and low-correlation coefficients obtained respectively for the UDS and LDS heights of occurrence and their corresponding mean PE illustrates that GW is one of the most generative mechanisms 5 for UDS layer. Similarly, the extracted PW display low- and high-amplitude for the UDS and LDS height region suggests the responsibility of PW in generating LDS. This is in agreement with wave propagation in the middle atmosphere. In fact, PW and most of GW are generated in the troposphere. PWs propagate upward and equator-ward with decreasing amplitudes toward tropics, while GWs propagate vertically with exponen10 tially increasing amplitudes. Though, the correlation of double stratopause observations, the GW and PW suggest that they are responsible for generating UDS and LDS structure, there might be a chance of combined wave activity. At this stage, we believe that the PW and GW activity may play a role in generating LDS and UDS structures. Additionally, GW breaking and associated turbulence nearby the stratopause region 15 might also contribute to the observed cooling in the stratopause height and thereby generating double stratopause. Further, we believe that the fast thermal adjustments and restoring force activity at the stratopause height region could also be behind the observed double stratopause. The purpose of the present issue is to report on seasonal and statistical characteristics of double stratopause occurrences as derived from 4-year observations of ground-based lidars operating in tropics, subtropics and mid-latitude. Future work will shade more light on the double stratopause formation mechanism by coupling in-situ observations and modelling.

Acknowledgements. The Laboratoire de l'Atmosphère et des Cyclones (LACy) is supported by the French Centre National de la Recherche Scientifique (CNRS)/Institut National des Sciences 25 de l'Univers (INSU) and the Conseil Régional de la Réunion. One of the authors, V. Sivakumar, acknowledges the Conseil Régional de la Réunion and the Funds Européen de développement Régional (FEDER), for the financial support under post-doctoral fellowship scheme. The National Atmospheric Research Laboratory (NARL) is operated by Department of Space (DOS), Government of India with partial support from Council of Scientific and Industrial Research 30 (CSIR).

Double stratospause structure

V. Sivakumar et al.

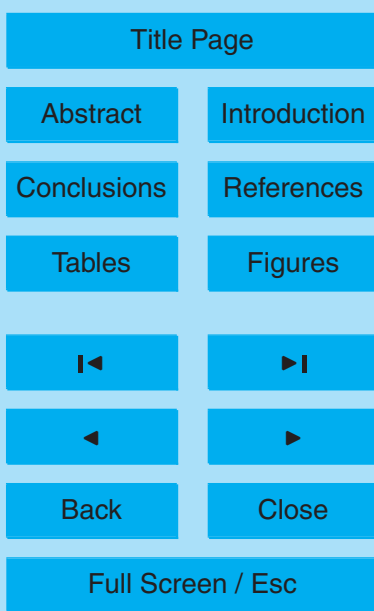

Printer-friendly Version

Interactive Discussion 


\section{References}

Allen, D. R., Stanford, J. L., Elson, L. S., Fishbein, E. F., Froidevaux, L., and Waters, J. W.: The 4-day wave as observed from the Upper Atmosphere Research Satellite Microwave Limb Sounder, J. Atmos. Sci., 54, 420-434, 1997.

5 Barnett, J. J. and Labitzke, K.: Climatological distribution of planetary waves in the middle atmosphere, Adv. Space Res., 10, (12), 63-91, 1990.

Chandra, H., Sharma, S., Acharya, Y. B., and Jayaraman, A.: A Rayleigh lidar study of the atmospheric temperature structure over Mt. Abu, India, J. Ind. Geophys. Union, 9, 279-298, 2005.

10 Gupta, R. K., Mohan, B., and Vernekar, K. G.: Thermal structure features of double stratopause over Thumba, India Journal Radio and Space Phys., 7, 277-286, 1978.

Hauchecorne, A. and Chanin, M. L.: Density and temperature profiles obtained by lidar between 35 and 70 km, Geophys. Res. Lett. , 8, 565-568, 1980.

Hauchecorne, A. and Chanin, M. L.: Mid-latitude lidar observations of planetary waves in the middle atmosphere during the winter of 1981-1982, J. Geophys. Res., 88, 3843-3849, 1983.

Hauchecorne, A., Chanin, M. L., and Wilson, R.: Mesospheric temperature inversion and gravity wave breaking, Geophys. Res. Lett., 14, 933-936, 1987.

Hitchman, M. H., Gille, J. C., Roddgers, C. D., and Brasseur, G.: The separated polar winter stratopause: A gravity wave driven climatological feature, J. Atmos. Sci., 46, 410-422, 1989.

Hirota, I.: Climatology of gravity waves in the middle atmosphere, in: dynamics of the middle atmosphere, edited by: Holton, J. R. and Matsuno, T., p. 65, Terra, Tokyo, 1984.

Keckhut, P., Hauchecorne, A., and Chanin, M. L.: A critical review on the data base acquired for the long term surveillance of the middle atmosphere by french rayleigh lidars,, J. Atmos. Oceanic Technol., 10, 850-867, 1993.

Leblanc, T., McDermid, I. S., Keckhut, P., Hauchecorne, A., She, C. Y., and Krueger, D. A.: Temperature climatology of the middle atmosphere from long-term lidar measurements at middle and low latitudes, J. Geophys. Res., 103, 17 191-17204, 1998.

Malinga, S. B. and Poole, L. M. G.: The 16-day variation in the mean flow at Grahamstown (33 $\left.{ }^{\circ} \mathrm{S}, 26.5^{\circ} \mathrm{E}\right)$, Ann. Geophysicae., 20, 2027-2031, 2002.

30 Ratnam, M. V., Nee, J. B., Chen, W. N., Sivakumar, V., and Rao, P. B.: Recent observations of mesospheric temperature inversions over a tropical station $\left(13.5^{\circ} \mathrm{N} ; 79.2^{\circ} \mathrm{E}\right), \mathrm{J}$. Atmos. Solar Terr. Phys., 65, 323-334, 2003.

Double stratospause structure

V. Sivakumar et al.

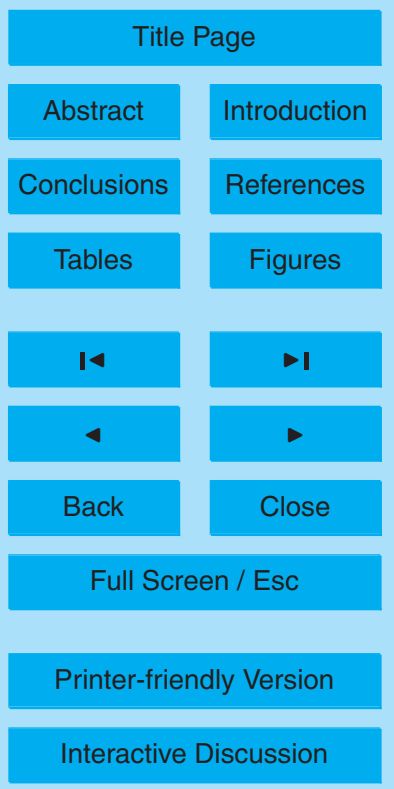

EGU 
Singh, U. N., Keckhut, P., McGee, T. J., Gross, M. R., Hauchecorne, A., Fishbein, E. F., Waters, J. W., Gille, J. C., Roche, A. E., and Russell, III J. M.: Stratosphere temperature measurements by two collocated NDSC lidars during UARS validation campaign, J. Geophys. Res., 101, 10287-10297, 1996.

5 Sivakumar, V., Bhavanikumar, Y., Raghunath, K., Rao, P. B., Krishnaiah, M., Mizutani, K., Aoki, T., Yasui, M., and Itabe, T.: Lidar measurements of mesospheric temperature inversion at a low latitude, Ann. Geophysicae, 19, 1039-1044, 2001.

Sivakumar, V.: Lidar studies of middle atmospheric temperature structure and tropospheric cirrus clouds over a low latitude., Ph.D Thesis, S.V. University, Tirupathi, A. P., India., 2002.

10 Sivakumar, V., Rao, P. B., and Krishnaiah, M.: Lidar measurements of stratospheremesosphere thermal structure over a low latitude: Comparison with satellite data and models, J. Geophys. Res., 108, D11, 4342, doi:10.1029/2002JD00 3029, 2003.

Sivakumar, V., Morel, B., Bencherif, H., Baray, J. L., Baldy, S., Hauchecorne, A., and Rao, P. B.: Rayleigh lidar observations of a warm stratopause over a tropical station, Gadanki $\left(13.5^{\circ} \mathrm{N}\right.$; 79.2 E), Atmos. Chem. Phys., 4, 1989-1996, 2004.

Sivakumar, V., Rao, P. B., and Bencherif, H.: Lidar observations of middle atmospheric gravity wave activity over a low latitude, Ann. Geophysicae, 24, 823-834, 2006.

Whiteway, J. A. and Carswell, A. I.: Rayleigh lidar observations of thermal structure and gravity wave activity in the high arctic during a stratospheric warming, J. Atmos. Sci., 51, 3122-3136, 201994.

Whiteway, J. A. and Carswell, A. I.: Lidar observations of gravity wave activity in the upper stratosphere over Toronto, J. Geophys. Res., 100, 14113-14124, 1995.

Wilson, R., Hauchecorne, A., and Chanin, M. L.: Gravity wave spectra in the middle atmosphere as observed by Rayleigh lidar, J. Geophys. Res., 96, 5153-5167, 1991a.

Wilson, R., Hauchecorne, A., and Chanin, M. L.: Gravity waves in the middle atmosphere observed by Rayleigh lidar, Part 2: Climatology, J. Geophys. Res., 96, 5169-5183, 1991b.

Double stratospause structure

V. Sivakumar et al.

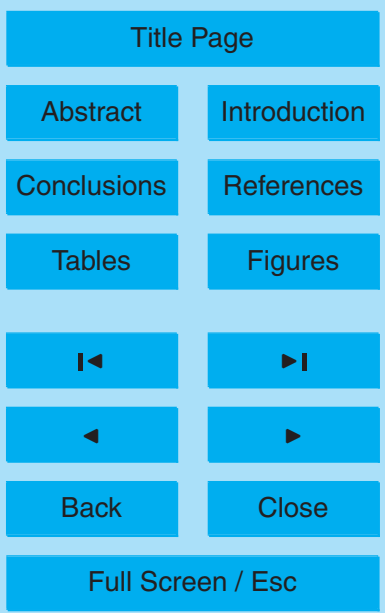

Printer-friendly Version

Interactive Discussion 


\section{ACPD}

6, 6933-6956, 2006

Table 1. Monthly distribution of total number of days and double stratopause occurrences over Gadanki $\left(13.5^{\circ} \mathrm{N}, 79.2^{\circ} \mathrm{E}\right)$, Mt. Abu $\left(24.5^{\circ} \mathrm{N}, 72.7^{\circ} \mathrm{E}\right)$ and $\mathrm{OHP}\left(44^{\circ} \mathrm{N}, 6^{\circ} \mathrm{E}\right)$.

\begin{tabular}{lcccccc}
\hline MONTH & \multicolumn{2}{c}{$\mathrm{GADANKI}^{\circ}$} & \multicolumn{2}{c}{$\mathrm{MT}$. ABU } & \multicolumn{2}{c}{ OHP } \\
& $\left(24.5^{\circ} \mathrm{N}, 72.7^{\circ} \mathrm{E}\right)$ & \multicolumn{2}{c}{$\left(44^{\circ} \mathrm{N}, 6^{\circ} \mathrm{E}\right)$} & \multicolumn{2}{c}{$\left(13.5^{\circ} \mathrm{N}, 79.2^{\circ} \mathrm{E}\right)$} \\
\hline & TOT $^{1}$ & DSC $^{2}$ & TOT & DSC & TOT & DSC \\
\hline January & 27 & 16 & 04 & 03 & 56 & 20 \\
February & 42 & 21 & 09 & 04 & 57 & 22 \\
March & 45 & 35 & 09 & 04 & 52 & 16 \\
April & 52 & 33 & 15 & 07 & 43 & 32 \\
May & 08 & 03 & 07 & 03 & 28 & 15 \\
June & 04 & 02 & 05 & 02 & 54 & 33 \\
July & 03 & 03 & - & - & 78 & 22 \\
August & 04 & 03 & - & - & 75 & 31 \\
September & 04 & 04 & 03 & 01 & 67 & 28 \\
October & 11 & 06 & 08 & 02 & 53 & 29 \\
November & 19 & 13 & 05 & 02 & 40 & 15 \\
December & 21 & 13 & 08 & 03 & 48 & 21 \\
Total & 240 & 152 & 73 & 31 & 651 & 284 \\
\hline
\end{tabular}

Double stratospause structure

V. Sivakumar et al.

Title Page

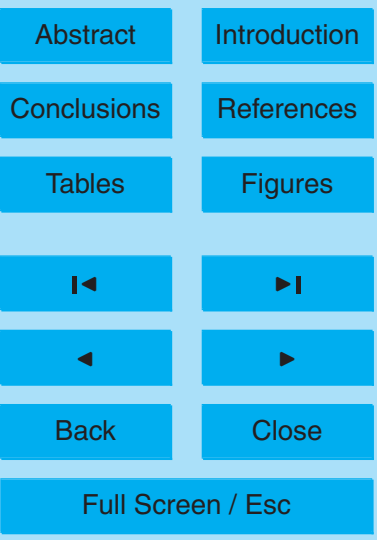

${ }^{1}$ Total number of observations and

${ }^{2}$ Double Stratopause cases. 


\section{ACPD}

6, 6933-6956, 2006

Double stratospause structure

V. Sivakumar et al.

Table 2. Mean values of NS, LDS and UDS for all the three stations during summer and winter.

\begin{tabular}{ccccccc}
\hline \multirow{2}{*}{ Station/Season } & \multicolumn{3}{c}{ SUMMER } & \multicolumn{3}{c}{ WINTER } \\
\cline { 2 - 7 } & NS & LDS & UDS & NS & LDS & UDS \\
\hline Gadanki $\left(13.5^{\circ} \mathrm{N}, 79.2^{\circ} \mathrm{E}\right)$ & 47.0 & 45.6 & 49.8 & 48.6 & 46.5 & 51.0 \\
Mt. Abu $\left(24.5^{\circ} \mathrm{N}, 72.7^{\circ} \mathrm{E}\right)$ & 48.1 & 46.5 & 53.0 & 47.3 & 46.8 & 49.2 \\
OHP $\left(44^{\circ} \mathrm{N}, 6^{\circ} \mathrm{E}\right)$ & 48.0 & 46.5 & 51.4 & 47.4 & 45.5 & 50.9 \\
\hline
\end{tabular}

Title Page

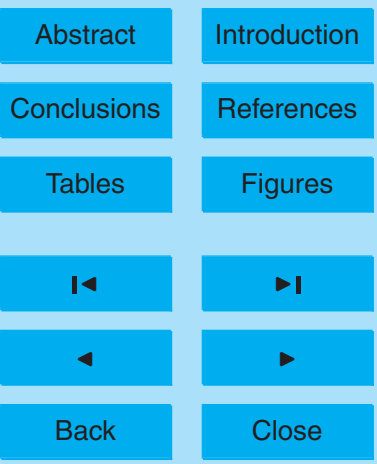

Full Screen / Esc

Printer-friendly Version

Interactive Discussion 


\section{ACPD}

\section{6, 6933-6956, 2006}

\section{Double stratospause structure}

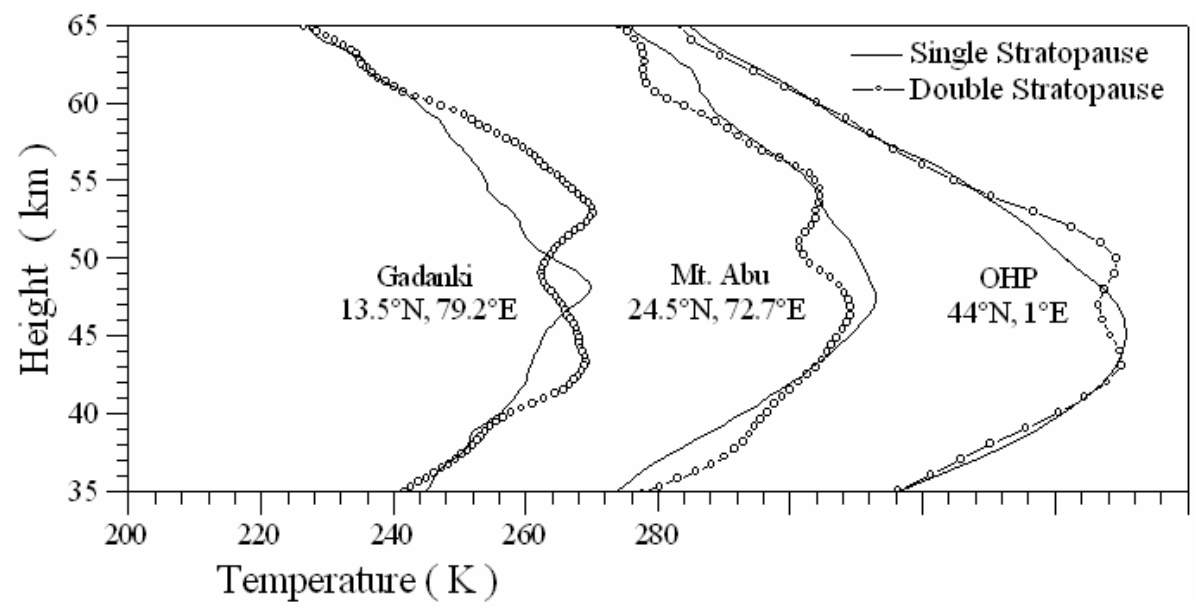

\section{Sivakumar et al.}

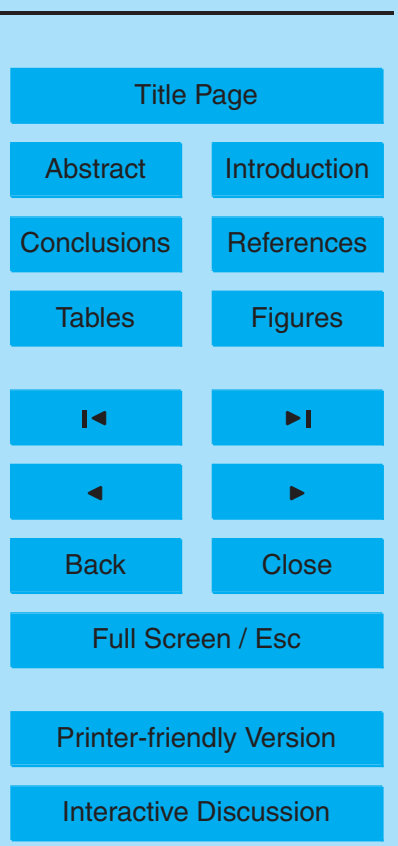



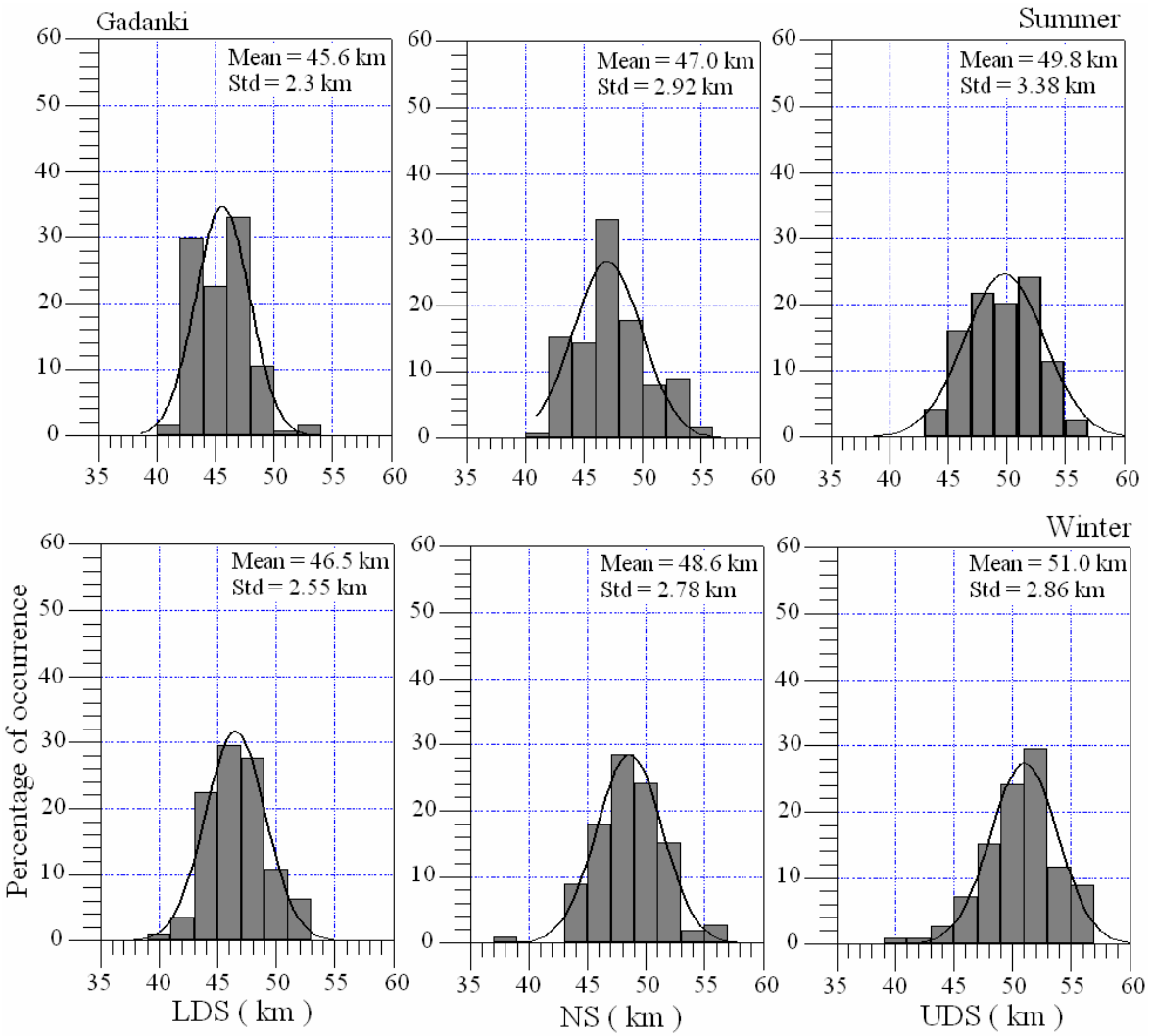

Fig. 2a. Frequency distribution of the Lower level of double stratopause (LDS), Normal Stratopause (NS) and Upper level of double stratopause (UDS) obtained by lidar observations from 1998 to 2001 over Gadanki during Summer and Winter.
ACPD

6, 6933-6956, 2006

Double stratospause structure

V. Sivakumar et al.

Title Page

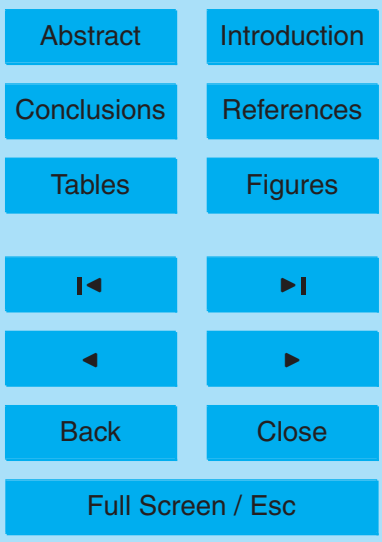

Printer-friendly Version

Interactive Discussion 

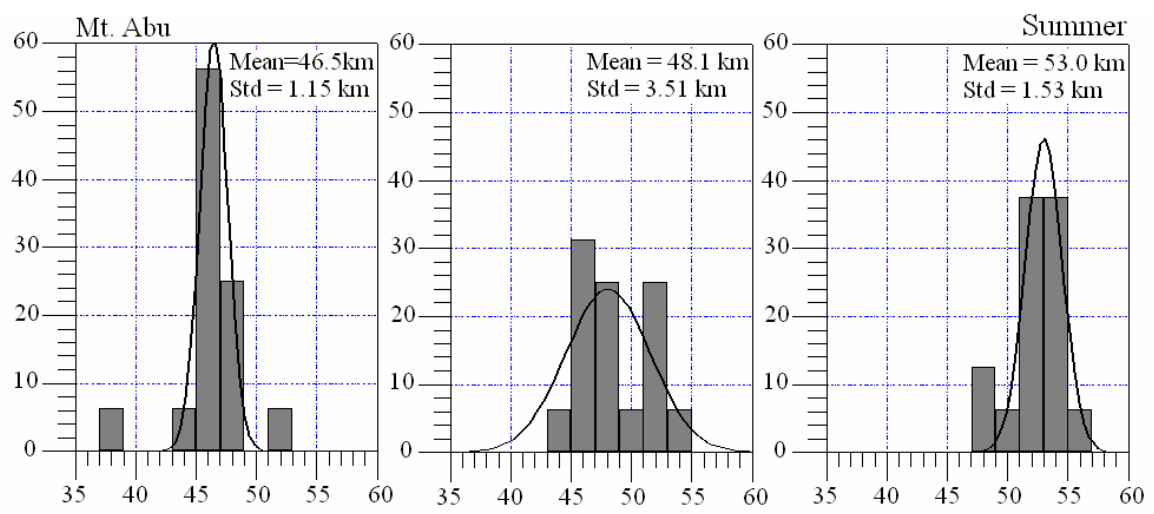

ACPD
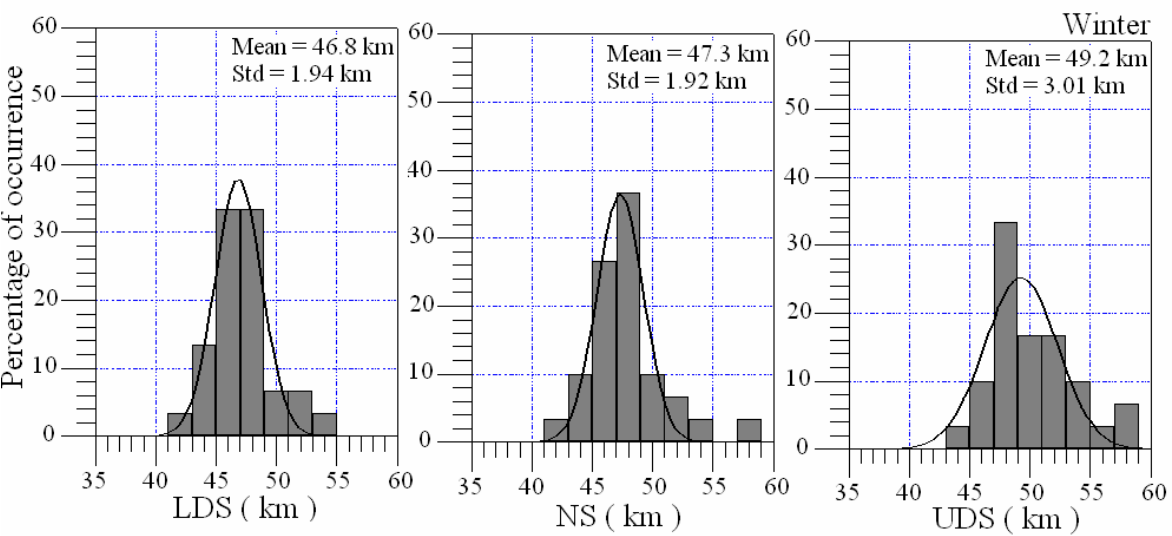

6, 6933-6956, 2006

Double stratospause structure

V. Sivakumar et al.

Title Page

Abstract

Conclusions

Tables

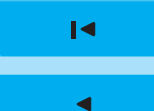

$\triangleleft$

\section{Back}

Fig. 2b. Same as Fig. 2a but for Mt. Abu.

Close

Introduction

References

Figures
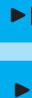

Printer-friendly Version

Interactive Discussion 

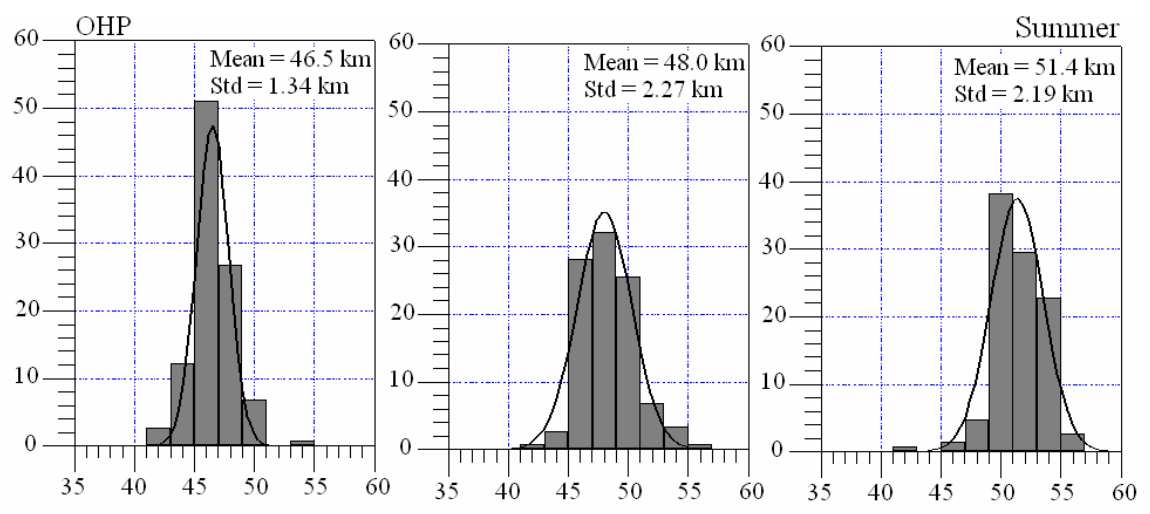

ACPD

6, 6933-6956, 2006
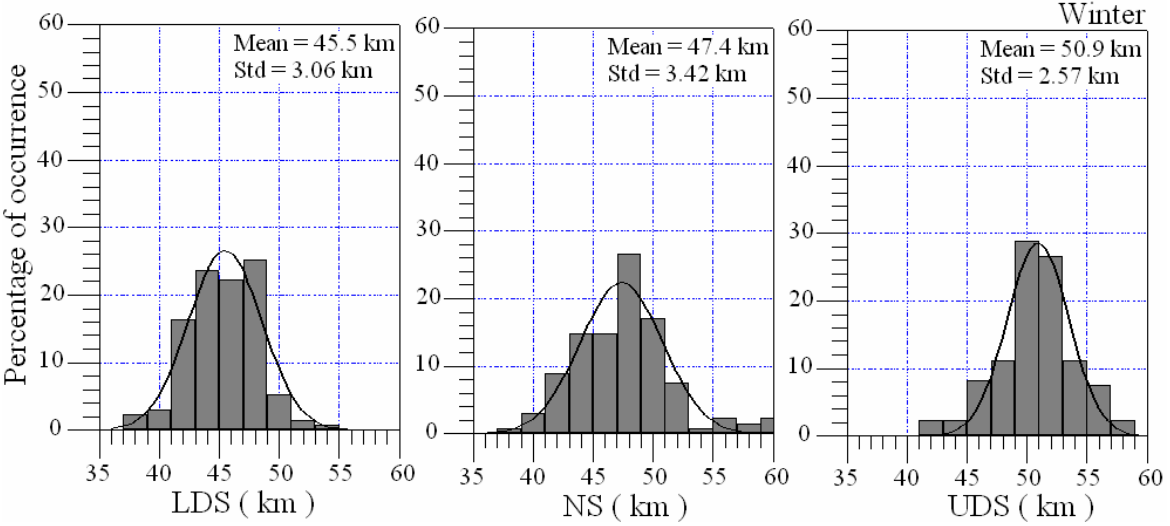

Double stratospause structure

V. Sivakumar et al.

Title Page

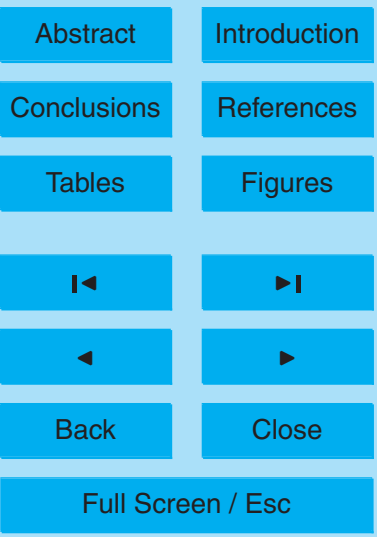

Printer-friendly Version

Fig. 2c. Same as Fig. 2a but for OHP.

Interactive Discussion 


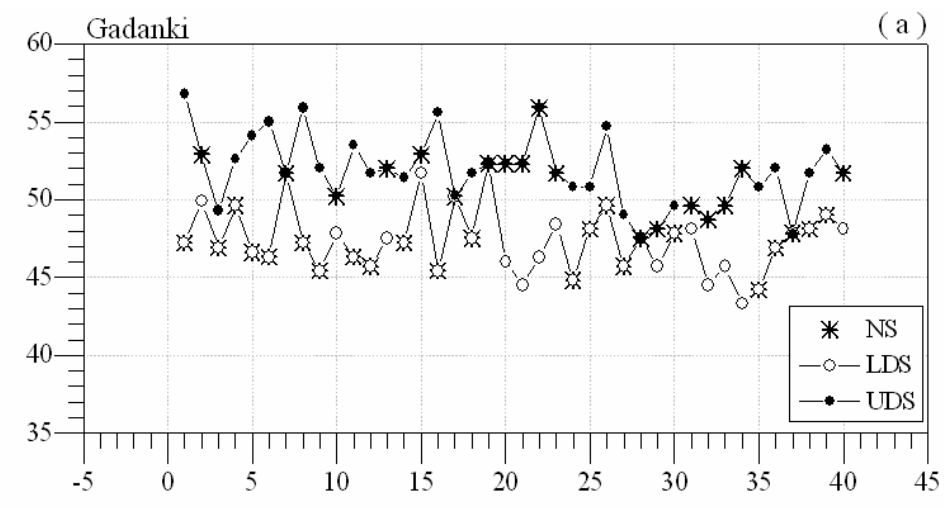

\section{ACPD}

6, 6933-6956, 2006

\section{Double stratospause} structure

V. Sivakumar et al.
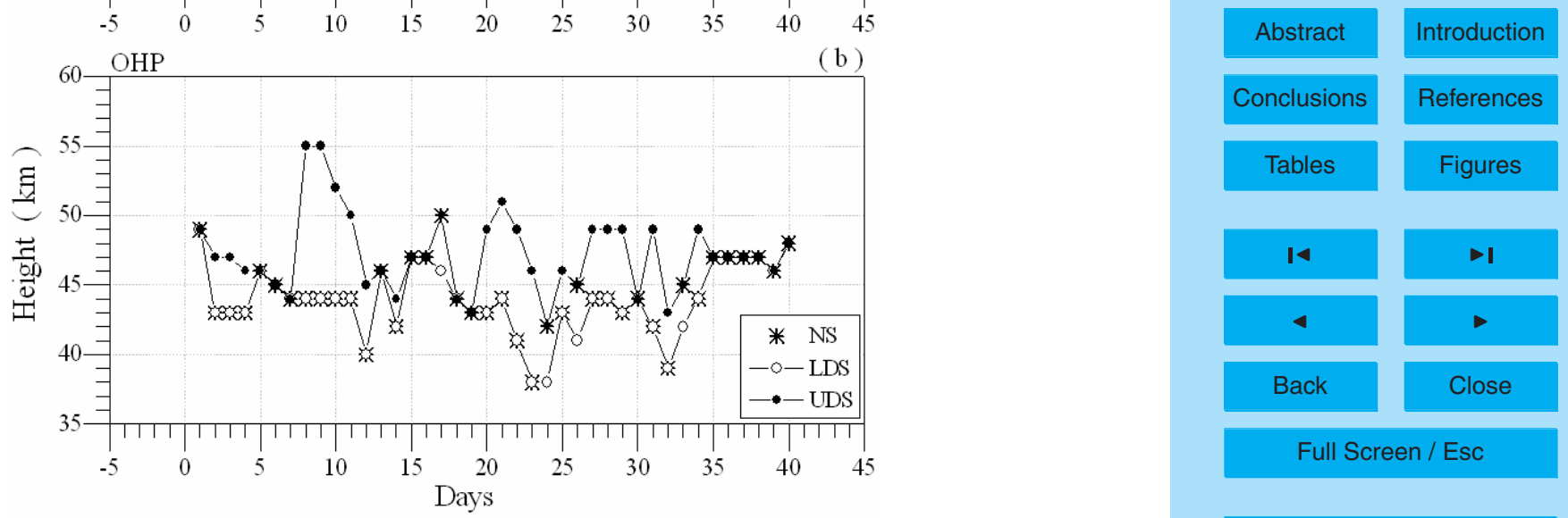

Fig. 3. The heights of occurrence of NS, LDS and UDS for quasi-continuous 40 days lidar observations from 18 January 1999 to 28 February 1999 (a) over Gadanki and (b) over OHP. The heights of occurrence of NS are either connected with LDS or with UDS. 


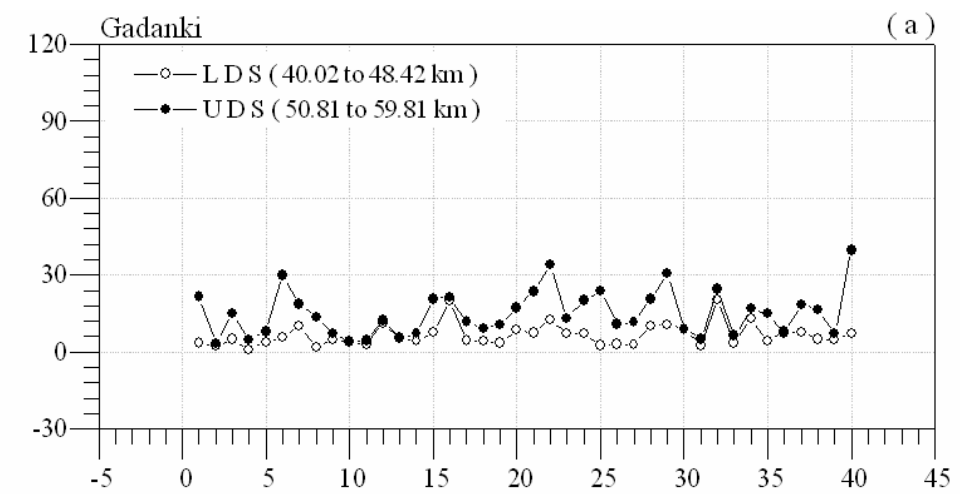

\section{ACPD}

6, 6933-6956, 2006

\section{Double stratospause} structure

V. Sivakumar et al.
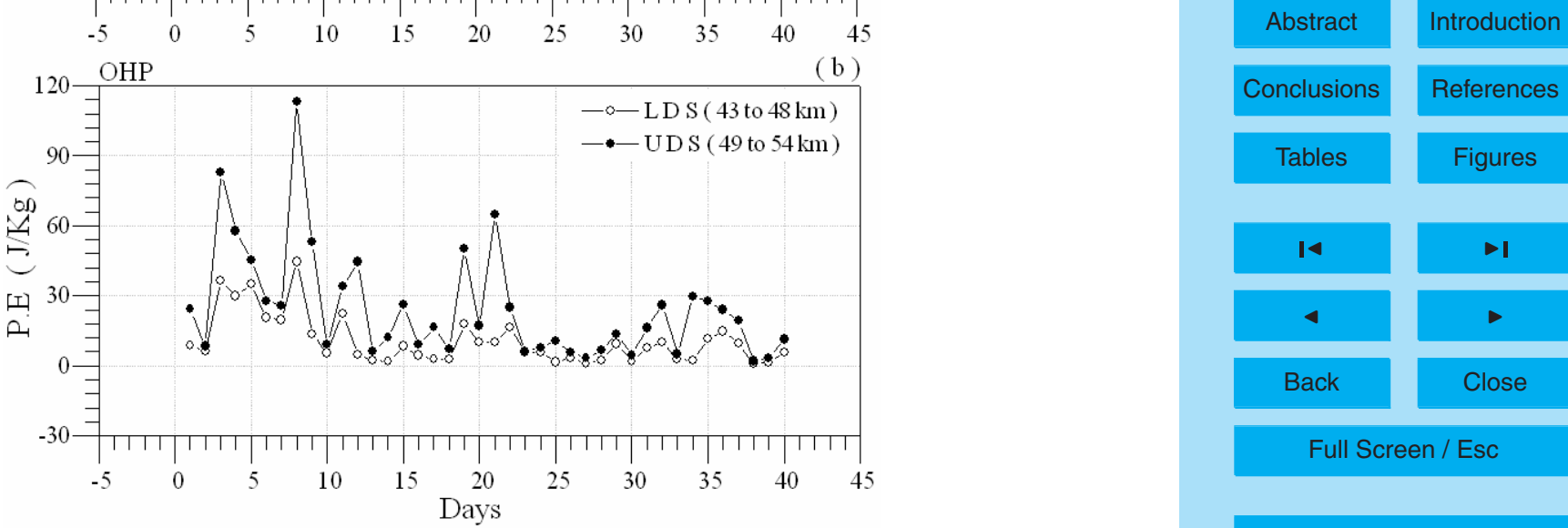

Printer-friendly Version

Fig. 4. Estimated mean PE for LDS and UDS height region for the same continuous 40-days lidar observations, presented in Fig. 3a and b, (a) over Gadanki and (b) over OHP. 


\section{ACPD}

6, 6933-6956, 2006

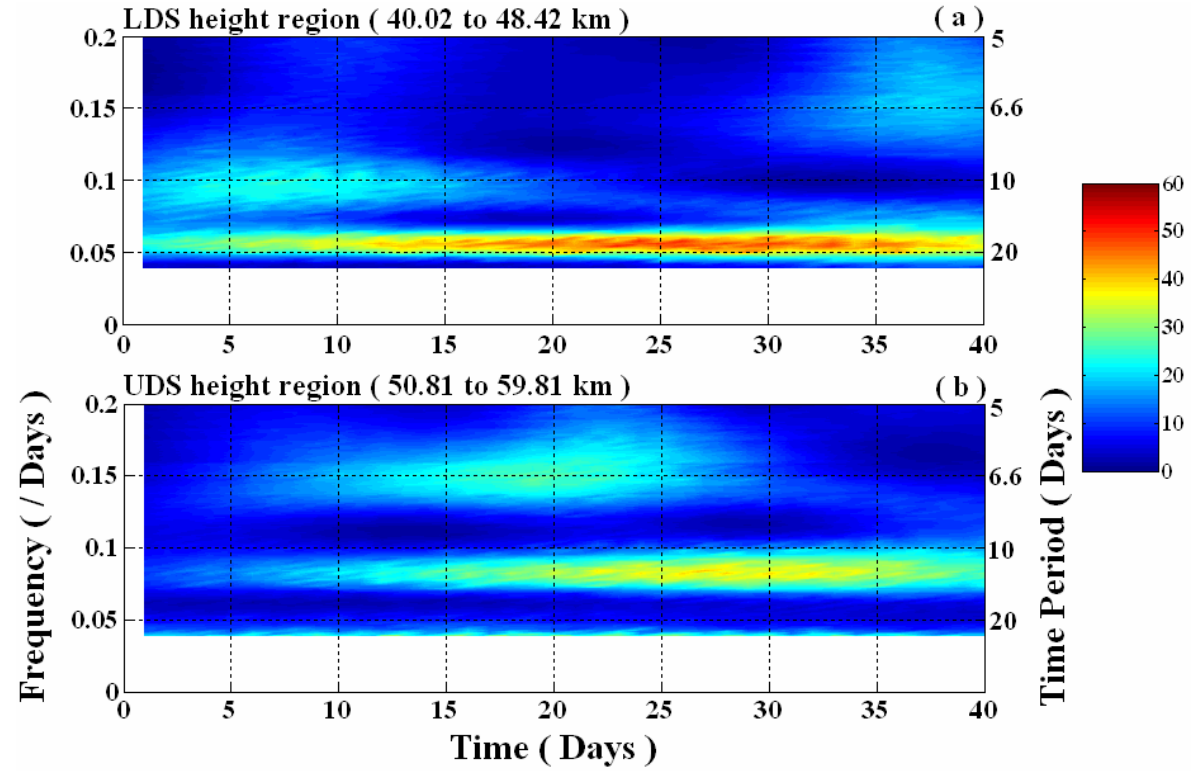

Double stratospause structure

V. Sivakumar et al.

Title Page

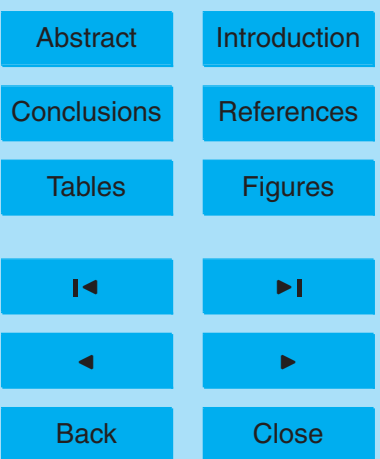

Full Screen / Esc

Fig. 5. The estimated mean PW amplitude obtained for the same period as in Fig. 3 for the LDS and UDS height regions over Gadanki.

Printer-friendly Version

Interactive Discussion 


\section{ACPD}

6, 6933-6956, 2006

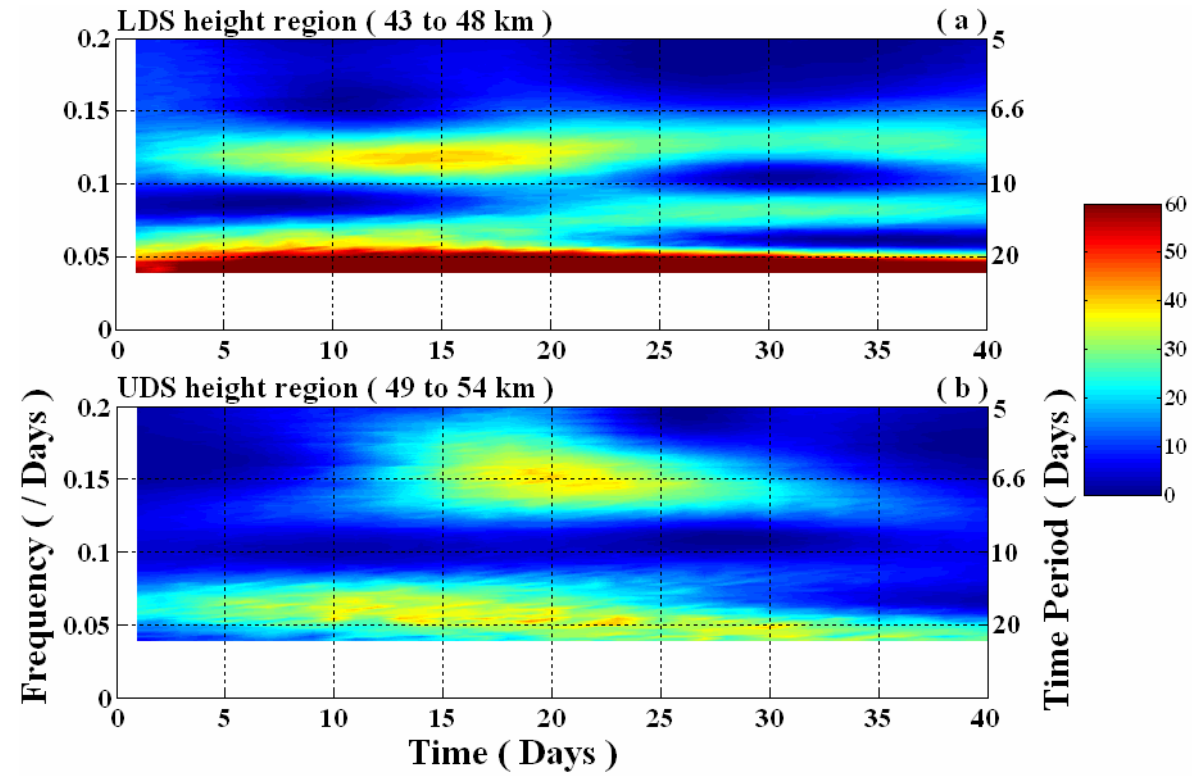

Double stratospause structure

V. Sivakumar et al.

Title Page

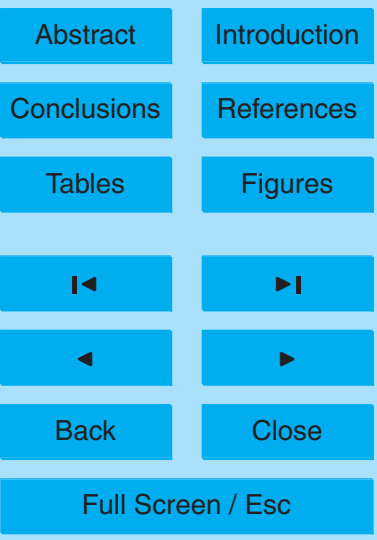

Fig. 6. Same as Fig. 5a and b, but for OHP.

Printer-friendly Version

Interactive Discussion 